\title{
Importance of kabuyutan sacred natural sites as biodiversity hotspots in West Java Province, Indonesia
}

$$
\text { ダーラン モハマド ザイニ*1) ・ 深町加津枝 }{ }^{1)} \text { - 柴田昌三 1) - 今西純一 1) }
$$

\author{
1）京都大学地球環境学大学院 Graduate School of Global Environmental Studies, Kyoto University
}

\begin{abstract}
摘要: 本研究はインドネシアのCiomas 村における 33 箇所の自然聖地である kabuyutanの生物多様性ホットスポットとしての重要性 を明らかにすることを目的とした。深層インタビューや参与観察を通した民族植物学のアプローチおよび植生調査により、対象地の 植物種を明らかにした。合計 332 種の植物が確認され、そのうち $38.5 \%$ が kabuyutanに分布した。生物多様性ホットスポットとし ての重要性が示された一方、半数が外来種となり、絶滅の恐れのある種もあった。予防的な措置により、外来種を取り除き、住民が 伝統儀式の中で外来種を植栽しないといった対策を進める必要がある。その上では、kabuyutanの管理者が環境保全と地域性に関し て持続可能な知識の共有が求められる。

キーワード : カブユタン，自然聖地，生物多様性ホットスポット，知識の共有，管理者の役割
\end{abstract}

DAHLAN, Mohammad Zaini, FUKAMACHI, Katsue, SHIBATA, Shozo, and IMANISHI, Junichi: インドネシア西ジャワ における自然の聖地 kabuyutanの生物多様性ホットスポットとしての重要性

Abstract: We aimed to highlight the current condition and the potential of 33 kabuyutan in Ciomas Village, Indonesia. The ethnobotanical approaches were used to identify plant species. Through the free listing method, about 332 plant species were reported and a third four of them existed in kabuyutan. The findings strengthened the potential of kabuyutan to be local biodiversity hotspots which would support the global conservation strategy. However, more than half of species were exotic. We suggested that dissemination of knowledge is essential to nourish people's awareness in dealing with locality and environmental conservation by encouraging and strengthening the custodian's role.

Key words: kabuyutan, sacred natural sites, biodiversity hotspot, knowledge sharing, custodian's role

\section{Introduction}

As one of the sacred natural sites that exist in a worldwide, kabuyutan are perceived having a potential to safeguard the biodiversity (Vodouhê et al., 2010). Historically, Sundanese philologist and archeologist report that the term of kabuyutan was used to define the sacred place that specified for the center of religious and education activities, settlement of priests, or conservation areas (Kartakusuma, 2006; Wessing, 1999). The evidence can be found in the ancient Sundanese manuscript such as Amanat ti Galunggung which explains their existence as a numinous place for respecting deities or ancestors (Kartakusuma, 2006). Physically, kabuyutan can be clearly distinguished from their surrounding landscape because a dense vegetation mainly covers it or characterized by particular sacred elements such as grave, spring, stone, lake, river, or even mountainous region. Local people have sanctified kabuyutan due to their believes that deities or spirits occupied these places and provided people certain powers such as the miraculous power to cure illness or to improve people's life with a blessing (Wessing, 1999).

Besides, the sacredness of kabuyutan shows the power of custodian in dealing with the ancestors' mandate to shield its importance. As a consequence, significant physical elements and associated historical and cultural values are remaining over periods. Recently, Sundanese scholars mostly put their attention into the historical artifact rather than natural element. This shows an excellent opportunity to reveal the ecological functions of kabuyutan. Therefore, this study was aimed to highlight the current condition and the potential of kabuyutan within the Sundanese landscape. Through this study, some adaptive strategies in dealing with challenges of kabuyutan are recommended.

\section{Materials and methods}

\subsection{Study site}

This study was carried out in Ciomas Village, Panjalu 
District, Ciamis Regency, West Java Province. Thirty-tree kabuyutan were explored with Kabuyutan Panghulu Gusti (KPG) as the largest and most respected which entitled by "heart of the village" due to its role in facilitating an annual nyepuh ceremony. As a part of the Sawal volcanic mountain (1762 m above sea level; hereafter masl), kabuyutan scattered within the village with the average elevation of 767 masl, more than half of them located on a very gentle slope (1-3\%) and only two kabuyutan placed on moderately sloping (5-15\%). Besides, the climatic condition is suitable for agricultural activities with the $25{ }^{\circ} \mathrm{C}$ of average daily temperature and wet season almost in a whole year with the average annual precipitation is about $2000 \mathrm{~mm}$. Most of the kabuyutan were placed close to water bodies and mainly covered by a dense vegetation. Sacred graves, springs and several sacred tree species existed (Figure 1a).

\subsection{Data collection}

The ethnobotanical approach was used through several methods to identify plant species within kabuyutan. First, key informants were asked to explain the plant species with their local names, habitat distribution, a variety of
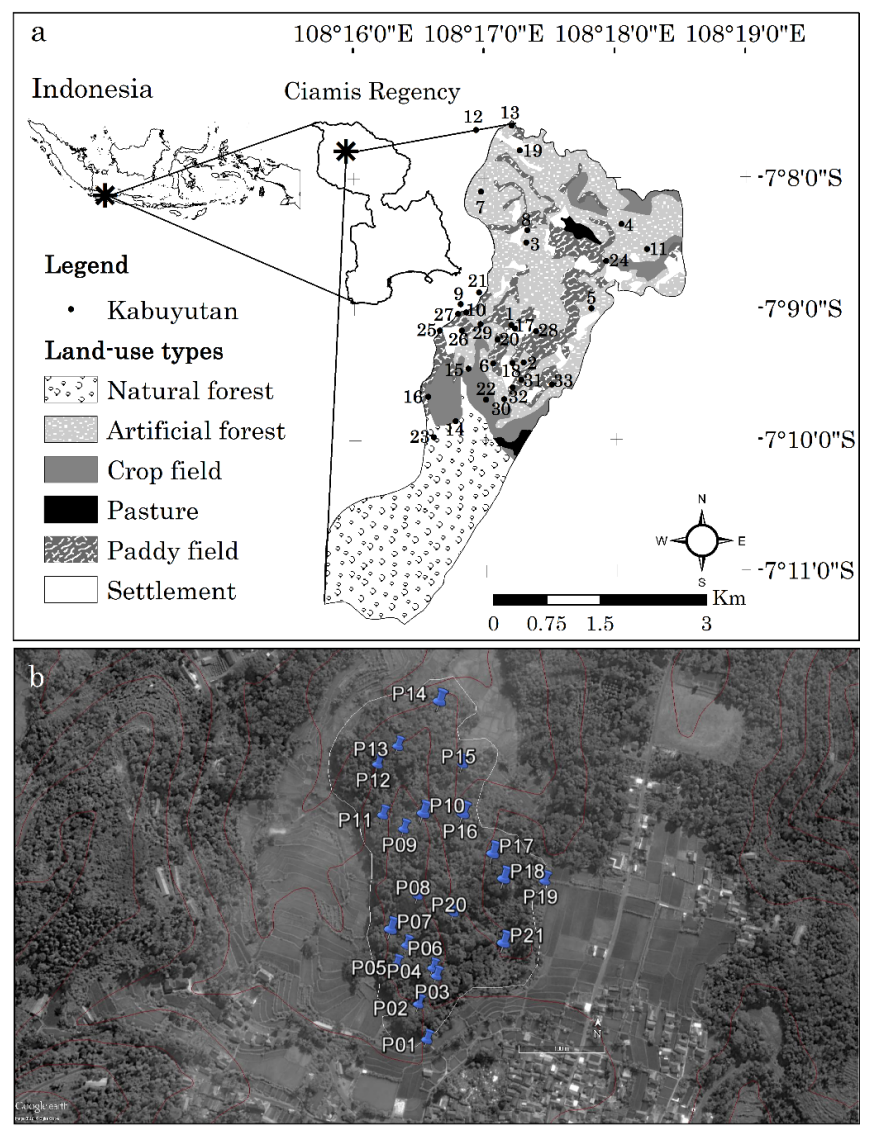

Fig. 1 Distribution of 33 kabuyutan (a) and 21 plots on the KPG (no. 1 in map) in Ciomas Village (b) uses, used part of the plant, as well as their appearance, condition, and utilization through the free listing method. Then, participant observation was conducted with key informants for deeper understanding the existence and the function of plant species that mentioned earlier. Besides, plots $\left(20 \times 20 \mathrm{~m}^{2}\right)$ were laid randomly to identify plant species that exist within kabuyutan as well as to verify what have been reported by informants. To avoid 'edge effects' distorting the data, peripheral areas, $3 \mathrm{~m}$ along the boundary or pedestrian track were excluded from the analysis except for kabuyutan which one or two plots per site. Tree species measuring $\geq 10 \mathrm{~cm}$ diameter at breast height (DBH), woody lianas, and other plant habitus with a height $\geq 1 \mathrm{~m}$ were enumerated (Figure $1 \mathrm{~b}$ ). All methods were applied during February 2015 and continued in March 2016.

\subsection{Data analysis}

Plant species database that obtained from participatory activity was verified by using The Plant List database (The Plant List, 2013) to check nomenclatural information. Also, the IUCN Red List and Indonesia protected plant database were used to verify whether the species was protected or common. Since the term of native species perceived by local people as species that have been existed in their location for long period regardless of the understanding about the origin of those plant species, we used the scientific definition of native proposed by Tallamy (2009) as species that have been observed particular place or ecosystem and existed for generations due to natural process. Based on those databases, native species were ascribed to Indonesia and West Java region in particular.

The cultural significance analysis of plant species was conducted by the quantitative assessment of important plant species in the ethnobotanical study. This analysis was necessary as a basis for considering the importance of particular plant species, their potential for both ecological conservation and social-economic purposes preservation (Turner, 1988). Also, this quantitative assessment is complementary to qualitative data that useful to deal with the environment issues, especially regarding plant species diversity (Hoffman and Gallaher, 2007). The Index of Cultural Significance (ICS) proposed by Turner (1988) was used to analyze the data. Turner (1988) suggested three necessary parameters in the cultural evaluation of plants which estimates of quality (q), intensity (i), and exclusivity value (e) of each plant of significance to the community (Table 1) with the following formula: $\operatorname{ICS}=\sum_{\mathrm{i}=1}^{n}(\mathrm{q} \times \mathrm{i} \times \mathrm{e}) \mathrm{u}_{\mathrm{i}}$ 
where, subscript $u_{i}$ shows $i$-th use type, and ICS is the sum of scores of use types from $u_{1}$ to $u_{n}$, with $n$ representing the last use described. We assumed that plant species with high ICS value have a potential to enrich plant diversity due to their relation to the local culture which regularly manages those plants. Further, the native species with high ICS value were assumed to have importance both in cultural and ecological aspect to support conservation strategy in biodiversity. Finally, results were discussed qualitatively to describe the phenomena.

\section{Results}

\subsection{Informant characteristics}

Five key informants of custodian's family, average age 44 years, participated in the study. They were native, Muslim, and none had a higher education grade than senior school. Agricultural activity was a primary source for their income. Also, they have been mandated to manage the kabuyutan and associated religious activities such as pilgrimage. The key informants were selected due to their status as the leading custodian of kabuyutan in Ciomas Village and KPG in particular. Local people respected them as an authorized person to deliver knowledge about kabuyutan.

\subsection{Ethnobotanical plant species in Ciomas Village}

According to informants' knowledge, a total of 332 different species were reported to exist in Ciomas Village which belongs to 100 families. Most of the families (50\%) have only one species, and Poaceae is a family that has the most species of 21 plant species (1.0\%). Plant species were majority identified as tree species $(43.4 \%)$ while epiphyte species were listed as the fewest (0.3\%) compare to others plant habitus. About three-quarter of plant species (71.7\%) was identified as exotic species, while 94 plant species (28.3\%) were recognized as native species. Five species were identified as threatened species by IUCN (1.6\%), while ten plant species were recognized as nationally protected species by Indonesia government due to their rarity in nature and difficulty in cultivation.

Informants reported about 24 combinations were identified to indicate habitat distribution of plant species. About 78 plant species (23.5\%) existed within kabuyutan, natural forest, and artificial forest area. About 11 plant species (3.3\%) were identified as ubiquitous plant species that live in all the habitat types (kabuyutan, natural forest, artificial forest, crop field, paddy field, and settlement area). Other findings showed that some unique plant species existed only in the natural forest $(0.3 \%)$, artificial forest $(1.5 \%)$, and settlement area (5.4\%). Regarding uses of the plant, informants reported that most of the plants were used for medicine (15.7\%) and environmental conservation purposes (14.7\%). A few number of species were used for fiber $(0.2 \%)$ such as Pinus mercusii and four species $(0.4 \%)$ such as Oryza sativa which majority of people use as staple food. Other utilizations were reported as for daily consumption such as fruits (9.3\%), vegetables (8.3\%), and spicy (4.1\%); for supporting household activities such as construction (9.4\%), fuel (8.2\%), industrial (2.2\%), and ornamental (4.8\%); as well as for supporting agriculture activities such as organic fertilizer (4.7\%), organic pesticide $(3.0 \%)$, and fodder $(8.7 \%)$. A whole part of plant species (22.1\%) was mainly used to fulfill local people's needs, especially for conservational purposes that require all part of the plant. Besides, people also used leaves $(21.6 \%)$ for daily consumption such as for cooking or curing the ailments; branches (11.8\%) for mainly used as firewood and charcoal; and stems (14.5\%) for construction materials as well as for industrial purposes.

Furthermore, Index of Cultural Significance (ICS) obtained for the 332-plant species useful for the Ciomas people ranged from 1 to 250. The highest value was for tisuk (Hibiscus macrophyllus Roxb. Ex. Hornem), while the lowest was dominated by the rare tree species such as angsana (Pterocarpus indicus Willd). Table 1 shows that only $8.1 \%$ of plant species were considered the very high significance and many species $(35.5 \%)$ were identified very low significance.

The highest value of ICS (Table 2) was dominated by trees function as timber for a specific use such as building material or furniture. For example, tisuk (Hibiscus

Table 1 Five groups of species based on ICS's analysis

\begin{tabular}{|c|c|c|}
\hline Value & Species & Important species (origin) \\
\hline $\begin{array}{l}\text { Very high } \\
\text { significance } \\
(\mathrm{ICS} \geq 100)\end{array}$ & 27 & $\begin{array}{l}\text { Tisuk (Hibiscus macrophyllus Roxb. Ex. } \\
\text { Hornem.) (E); jati (Tectona grandis L.f.) (N); } \\
\text { jati bodas (Gmelina arborea Roxb.) (E); afrika } \\
\text { (Maesopsis eminii Engl.) (E); alba (Albizia } \\
\text { falcataria (L.) Fosberg) (E) }\end{array}$ \\
\hline $\begin{array}{l}\text { High } \\
\text { significance } \\
\text { (ICS 50-99) }\end{array}$ & 45 & $\begin{array}{l}\text { Jagung (Zea mays L.) (E); padi (Oryza sativa } \\
\text { L.) (E); nangka (Artocarpus heterophylus } \\
\text { Merr.) (N) }\end{array}$ \\
\hline $\begin{array}{l}\text { Moderate } \\
\text { significance } \\
\text { (ICS 20-49) }\end{array}$ & 54 & $\begin{array}{l}\text { Awi haur (Bambusa tuldoides) (E); padi } \\
\text { huma (Oryza sp.) (E); jengkol (Pithecelobium } \\
\text { lobatum Benth.) (N) }\end{array}$ \\
\hline $\begin{array}{l}\text { Low } \\
\text { significance } \\
\text { (ICS 5-19) }\end{array}$ & 88 & $\begin{array}{l}\text { Cecenet (Physalis angulata L.) (E); dalima } \\
(\text { Punica grandum L.) (E); awi hideung } \\
\text { (Gigantochloa atroviolacea) }(\mathrm{N})\end{array}$ \\
\hline $\begin{array}{l}\text { Very low } \\
\text { significance } \\
\text { (ICS 1-4) }\end{array}$ & 118 & $\begin{array}{l}\text { Anggrek (Phalaenopsis javanica Blumei.) (N); } \\
\text { angsana (Pterocarpus indicus Willd.) }(\mathrm{N}) ; \\
\text { antanan }(\text { Centella asiatica (L.) Urban.) }(\mathrm{N})\end{array}$ \\
\hline
\end{tabular}

Abbreviation: Origin of plant species, native (N) or exotic (E) 
Table 2 Calculation of species with the highest ICS's value

\begin{tabular}{|c|c|c|}
\hline Species & Detailed calculation & ICS \\
\hline $\begin{array}{l}\text { Tisuk (Hibiscus } \\
\text { macrophyllus Roxb. Ex. } \\
\text { Hornem.) }\end{array}$ & $\begin{array}{l}(4 \times 5 \times 2) \mathrm{u}_{5}+(3 \times 5 \times 2) \mathrm{u}_{6}+(4 \times 5 \times 2) \mathrm{u}_{7}+ \\
(4 \times 5 \times 2) \mathrm{u}_{8}+(2 \times 5 \times 2) \mathrm{u}_{11}+(2 \times 5 \times 2) \mathrm{u}_{12}+ \\
(2 \times 5 \times 2) \mathrm{u}_{13}+(4 \times 5 \times 2) \mathrm{u}_{14}\end{array}$ & 250 \\
\hline $\begin{array}{l}\text { Jati (Tectona grandis } \\
\text { L.f.) }\end{array}$ & $\begin{array}{l}(4 \times 5 \times 2)_{\mathrm{u}_{5}}+(3 \times 5 \times 2)_{\mathrm{u}_{6}}+(4 \times 5 \times 2)_{\mathrm{u}_{7}}+ \\
(4 \mathrm{x} 5 \times 2)_{\mathrm{u}_{8}}+(2 \times 5 \times 2)_{\mathrm{u}_{11}}+(4 \mathrm{x} 5 \times 2)_{\mathrm{u}_{13}}\end{array}$ & 210 \\
\hline $\begin{array}{l}\text { Jati bodas (Gmelina } \\
\text { arborea Roxb.) }\end{array}$ & $\begin{array}{l}(4 \times 5 \times 2) u_{u_{5}}+(3 \times 5 \times 2)_{u_{6}}+(4 \times 5 \times 2) u_{u_{7}}+ \\
(4 \times 5 \times 2)_{u_{8}}+(2 \times 5 \times 2)_{u_{11}}+(4 \times 5 \times 2) u_{u_{13}}\end{array}$ & 210 \\
\hline $\begin{array}{l}\text { Afrika (Maesopsis eminii } \\
\text { Engl.) }\end{array}$ & $\begin{array}{l}(4 \times 5 \times 2)_{u_{5}}+(3 \times 5 \times 2)_{u_{6}}+(4 \times 5 \times 2)_{u_{7}}+ \\
(4 \times 5 \times 2)_{u_{8}}+(4 \times 5 \times 2)_{u_{13}}+(4 \times 5 \times 2)_{u_{14}}\end{array}$ & 200 \\
\hline $\begin{array}{l}\text { Alba (Albizia falcataria } \\
\text { (L.) Fosberg) }\end{array}$ & $\begin{array}{l}(4 \times 5 \times 2))_{u_{5}}+(3 \times 5 \times 2)_{u_{6}}+(4 \times 5 \times 2) u_{u_{7}}+ \\
\left.(4 \times 5 \times 2)_{u_{8}}+(4 \times 5 \times 2)_{u_{13}}+(4 \times 5 \times 2)\right)_{u_{14}}\end{array}$ & 200 \\
\hline
\end{tabular}

Note: subscript $u_{i}$ shows the individual use of plant species for food $\left(\mathrm{u}_{1}\right)$, fruit $\left(\mathrm{u}_{2}\right)$, vegetable $\left(\mathrm{u}_{3}\right)$, spicy $\left(\mathrm{u}_{4}\right)$, fodder $\left(\mathrm{u}_{5}\right)$, construction $\left(\mathrm{u}_{6}\right)$, industrial $\left(\mathrm{u}_{7}\right)$, fuel $\left(\mathrm{u}_{8}\right)$, fiber $\left(\mathrm{u}_{9}\right)$, ornamental $\left(\mathrm{u}_{10}\right)$, medicine $\left(\mathrm{u}_{11}\right)$, spiritual $\left(\mathrm{u}_{12}\right)$, conservation $\left(\mathrm{u}_{13}\right)$, organic fertilizer $\left(\mathrm{u}_{14}\right)$, and organic pesticide $\left(\mathrm{u}_{15}\right)$

macrophyllus Roxb. Ex. Hornem) that used for construction material $\left(u_{6}\right)$ and industrial $\left(u_{7}\right)$ has a very high intensity of use ( $\mathrm{i}=5)$ which used regularly $(\mathrm{q}=4)$ and more preferred over other plant use options $(e=2)$. Informants reported that after Indonesia government proclaiming the program of One Million Tree for Indonesia in 2010, government encouraged timber tree plantation such as tisuk, jati, jati bodas, afrika, dan alba (Table 2) to increase the prosperity in addition to environmental conservation purposes. To date, people have been planting those tree species in their forest garden, mixed garden, or even home garden as a deposit for future needs.

\subsection{Plant species in kabuyutan}

Informants reported that 249 plant species exist in kabuyutan and about 96 plant species belong to 47 families have been clarified within 33 kabuyutan (Table 3). Most species were identified as tree (77.1\%) following by herb $(5.2 \%)$, bamboo $(4.2 \%)$, liana $(4.2 \%)$, palm tree $(4.2 \%)$, pandanus (2.1\%), shrub (2.1\%), and fern (1.0\%) respectively. About 58 species (60.4\%) were exotic, and the majority of species were not designated as a protected plant species both by IUCN (97.9\%) and national regulation (94.8\%). Concerning utilization, most species were found in nature as a wild plant (65.6\%), and none were regularly cultivated. A half of species indicated rarity while $28.1 \%$ of species were abundant. As for utilization, more than half of species (56.3\%) were used in a little amount which considered as a sufficiency.

Results showed that some endangered plant species existed in kabuyutan. For example, a native and IUCN's threatened tanglar tree (Aglaia elliptica Blume, Bijdr)
Table 3 Vegetation survey of 33 kabuyutan

\begin{tabular}{|c|c|c|c|c|c|}
\hline $\begin{array}{c}\text { Kabuyutan } \\
\text { (number in map) }\end{array}$ & TA & LS & $\mathrm{NP}$ & $\mathrm{NS}(\mathrm{N}, \mathrm{E})$ & NT \\
\hline Panghulu Gusti (1) & 6.6 & $\mathrm{G}$ & 21 & $58(25,33)$ & 45 \\
\hline Kawis (2) & 3.3 & $\mathrm{G}$ & 7 & $9(5,4)$ & 7 \\
\hline Ciomaslandeuh (3) & 2.2 & $\mathrm{G}$ & 3 & $10(6,4)$ & 7 \\
\hline Sereh (4) & 2.1 & $\mathrm{G}$ & 6 & $23(11,12)$ & 17 \\
\hline Mangkubumi (5) & 1.7 & $\mathrm{G}$ & 2 & $15(5,10)$ & 10 \\
\hline Kituak (6) & 1.2 & $\mathrm{P}$ & 1 & $6(3,3)$ & 2 \\
\hline Galogor (7) & 1.1 & $\mathrm{P}$ & 2 & $7(3,4)$ & 6 \\
\hline Borogojol (8) & 1.1 & $\mathrm{P}$ & 3 & $10(5,5)$ & 8 \\
\hline Makambaros (9) & 1.0 & $\mathrm{G}$ & 4 & $18(7,11)$ & 16 \\
\hline Cikutuk (10) & 1.0 & $\mathrm{P}$ & 2 & $7(2,5)$ & 4 \\
\hline Semang (11) & 0.8 & $\mathrm{P}$ & 4 & $21(8,13)$ & 13 \\
\hline Ranjeng (12) & 0.7 & $\mathrm{G}$ & 2 & $10(6,4)$ & 7 \\
\hline Pasirjambu (13) & 0.7 & $\mathrm{G}$ & 3 & $18(9,9)$ & 13 \\
\hline Embungcidarma (14) & 0.7 & $\mathrm{P}$ & 2 & $3(0,3)$ & 3 \\
\hline Hulusitu (15) & 0.6 & $\mathrm{P}$ & 3 & $7(2,5)$ & 3 \\
\hline Seureuhbeureum (16) & 0.5 & $\mathrm{G}$ & 3 & $8(2,5)$ & 2 \\
\hline Wargabangsa (17) & 0.4 & $\mathrm{G}$ & 1 & $4(2,2)$ & 3 \\
\hline Gencoy (18) & 0.3 & $\mathrm{P}$ & 1 & $8(4,4)$ & 3 \\
\hline Pasucian (19) & 0.3 & $\mathrm{P}$ & 1 & $11(2,9)$ & 8 \\
\hline Kijoho $(20)$ & 0.3 & $\mathrm{P}$ & 2 & $14(5,9)$ & 10 \\
\hline Cipambuangan (21) & 0.2 & $\mathrm{P}$ & 2 & $16(5,11)$ & 10 \\
\hline Batudatar (22) & 0.2 & $\mathrm{P}$ & 1 & $2(1,1)$ & 0 \\
\hline Cipanyusuhan (23) & 0.2 & $\mathrm{G}$ & 1 & $2(0.2)$ & 2 \\
\hline Cidarma-Cigarunggang (24) & 0.2 & $\mathrm{P}$ & 1 & $11(4,7)$ & 7 \\
\hline Pangauban (25) & 0.2 & $\mathrm{P}$ & 1 & $4(1,3)$ & 2 \\
\hline $\operatorname{Baros}(26)$ & 0.2 & $\mathrm{G}$ & 1 & $9(0,9)$ & 6 \\
\hline Gunungsari (27) & 0.1 & $\mathrm{P}$ & 1 & $5(1,4)$ & 3 \\
\hline Awilarangan (28) & 0.1 & $\mathrm{P}$ & 1 & $4(2,2)$ & 1 \\
\hline Picung (29) & 0.1 & $\mathrm{P}$ & 1 & $8(1,7)$ & 6 \\
\hline Cigondok (30) & 0.0 & $\mathrm{P}$ & 1 & $1(0,1)$ & 0 \\
\hline Nusakutu (31) & 0.0 & $\mathrm{P}$ & 1 & $2(1,1)$ & 1 \\
\hline Kitiwu (32) & 0.0 & $\mathrm{P}$ & 1 & $2(1,1)$ & 1 \\
\hline Kimulud (33) & 0.0 & $\mathrm{P}$ & 1 & $3(0,3)$ & 2 \\
\hline
\end{tabular}

Abbreviation: Elevation (E) in masl; total area (TA) in hectare; land status (LS) owned by government $(\mathrm{G})$ and private $(\mathrm{P})$; number of plot (NP); number of species (NS) with number of native $(\mathrm{N})$ and exotic species (E); and number of trees (NT)

(Pannell, 1998) was perceived has a high cultural significance due to its existence for an extended period and well known as the main symbol of KPG. The rarity has caused this species to be sacred and restricted to its utilization. In contrast with tanglar, kawung (Arenga pinnata (Wurmb) Merr.) were found in a nearly half of kabuyutan. This species was also perceived as a culturally significant species for Sundanese people who has obtained its benefits for generations. Informants stated that kawung 


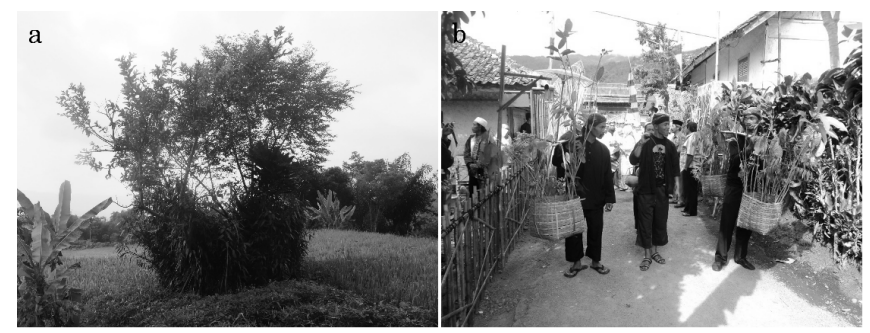

Fig. 2 Condition of Kabuyutan Cigondok (a); and a rite of tree plantation in the annual nyepuh ceremony (b)

is essential for environmental conservation due to its capability to catch and store water as well as to maintain the structure of the soil. However, they found some difficulties to cultivate this species because of the extinction of careuh, or the common palm civet (Paradoxurus hermaphroditus) which perceived has a mutual symbiosis with kawung. Informants said that the seeds would be easier to grow after the fermentation process through civet's digestion. They also mentioned that the decreasing number of careuh in line with the increasing of the coffee plantation to produce kopi luwak (civet coffee). Furthermore, IUCN listed as least concern species (Duckworth et al., 2016).

In addition to the endangered species, an interesting result was found that kalapa ciung (Ailanthus triphysa) and pasang (Lithocarpus elegans (Blume) Hastus. Ex Soepadmo) were distributed almost over the whole kabuyutan which counted fifteen plots and ten plots respectively. Informants reported that similar with kawung, kalapa ciung also perceived as both culturally and ecologically significant tree. This tree was perceived for marking the lands susceptible to a landslide as well as for identifying the sacredness of kabuyutan.

Concerning the importance of tree as a dominant species without compromising other plant habitus, at least 74 trees existed within kabuyutan (Table 3). The majority of tree species were found in KPG as the largest kabuyutan in Ciomas Village and other kabuyutan located on government lands such as Sereh and Mangkubumi. Informants reported that annual ceremony of nyepuh in the KPG which requires tree plantation as a part of rituals has a potential to increase the number of species (Figure $1 \mathrm{~b}$ and $2 \mathrm{~b}$ ). Recently, at least three tree species, namely sirsak (Annona muricata L.), palahlar (Dipterocarpus retusus BI.), and matoa (Pometia pinnata J.R. Forst\&G. Forst.) were planted during nyepuh. Since 2016, selection of plant species was conducted to ensure the origin of species. In addition, the national afforestation program has been actively encouraged people to plant tree species regardless of their origin. As a consequent, five species with the highest ICS value were also found within kabuyutan.

As for other large kabuyutan, natural succession followed by the sacredness of such places led to maintain the number tree species. On the contrary, Kabuyutan Cigodok has lost its surrounding area which previously covered by trees (Figure 2a). Other results found that kabuyutan located on private lands showed the less number of species due to the landowner's interest. Some informants stated that people are usually utilizing their land based on their wish to fulfill their basic need which mainly to produce a staple food such as rice or other complementary crops. Thus, most of privately kabuyutan were surrounded by paddy or crop field area. Consequently, the area of kabuyutan was gradually fragmented and some of them existed only with their single elements such as graves, stones, plants, or spring.

\section{Discussion}

Results revealed that 249 (75\%) of 332 plant species were reported to exist in kabuyutan according to local people's knowledge and 96 (38.5\%) of them have been verified based on vegetation survey. It is assumed that kabuyutan is potential to be hotspots of plant diversity. This finding supports other studies that proposed a function of sacred natural sites as a preferable habitat for abundant plant species (Dudley et al., 2010). In addition, regardless of survey's result, the presence of all fifteen endangered plant species as well as $32.9 \%$ of native species reported by informants, indicating the importance of kabuyutan towards biodiversity conservation. The presence of endemic and threatened species is important in designating a biodiversity hotspot that leads to making up conservation priorities (Myers et al., 2000). It shows a potential for kabuyutan to be acknowledged as local biodiversity hotspot to support regional or further global conservation efforts.

The existence of plant species highly depends on the cultural aspect that influences the management of kabuyutan. The tradition which held in kabuyutan plays an important role to maintain the plant species. An annual ceremony of nyepuh that owned by local people in KPG, for instance, requires some tree species to be planted as a part of rituals regardless of plant origin. Consequently, the number of exotic species might be increasing in line with the implementation of ceremony such as shown in the KPG with the 33 exotic plant species compared to 25 native species (Table 3). However, a change of perception according to native species led to prevent the introduced 
species. As a result, two native tree species (matoa and palahlar) have been planted during nyepuh in 2016 . Moreover, palahlar tree is assessed as a vulnerable species by IUCN due to decreasing of the population within its habitat (Ashton, 1998).

Similar to other studies (Vodouhê et al., 2010), this study stresses that dissemination of knowledge is essential to change people's perception that will influence their awareness to protect their valuable properties. Furthermore, this effort is also essential to increase the landowner's awareness (Honig et al., 2015) in managing kabuyutan, especially according to the importance of trees in land and water conservation. Therefore, this study emphasis that the availability of related information needs to be prepared in advance and encouraging their participation (Vodouhê et al., 2010) is also important, especially to deal with the locality (Cook et al., 2015).

Furthermore, a sufficient knowledge may strengthen the essential role of custodian through their customary laws to encourage local people and government to use local species in the nyepuh ceremony as well as during afforestation program. Consequently, this effort can revitalize the cultural significance of native plant species and also can improve the capability of kabuyutan and their buffer zone as local biodiversity hotspots.

\section{Conclusion}

The finding that a third four of plant species in Ciomas Village exist in kabuyutan reinforce the potential of kabuyutan to be local biodiversity hotspots. However, some preventive efforts should be applied to eliminate the dominance of exotic species such as strengthened the selection of plant species when performing nyepuh tradition as well as when implementing afforestation in and around kabuyutan. We suggested that dissemination of knowledge related to the importance of kabuyutan and its element is essential to increase local people's awareness by strengthening the custodian's role. Moreover, there is a potential to combine customary laws and official regulations in the management strategy to ensure the sustainability of kabuyutan. Finally, a further analysis on vegetation is essential for deeper understanding about the importance of kabuyutan.

Acknowledgement : Thank to Beatrix Yoshikawa for precious critique and proofreading. This research was supported by The Indonesia Endowment Fund for Education (LPDP).

\section{References}

1) Ashton, P. (1998) Dipterocarpus retusus. The IUCN Red List of Threatened Species 1998: e.T32400A9702185. http://www.iucnredlist.org/details/32400/0 (Accessed: 24Jan-2017).

2) Cook, N. A., Sarver, E. A., Krometis, L. H., and Huang, J. (2015) Habitat and water quality as drivers of ecological system health in Central Appalachia. Ecol.Eng., 84:180-189.

3) Duckworth, J. W., Timmins, R. J., Choudhury, A., ... Xu, W. (2016) Paradoxurus hermaphroditus. The IUCN Red List of Threatened Species 2016: e.T41693A45217835. http://www.iucnredlist.org/details/41693/0 (Accesed: 21Feb-2017)

4) Dudley, N., Bhagwat, S., Higgins-Zogib, L., Lassen, B., Verschuuren, B., and Wild, R. (2010). Conservation of biodiversity in sacred natural sites in Asia and Africa: a review of the scientific literature. In: Sacred natural sites: conserving nature and culture (eds. B. Verschuuren, R. Wild, J. McNeely, and G. Oviedo) pp. 19-32, London \& Washington, DC: Earthscan.

5) Hoffman, B., and Gallaher, T. (2007) Importance indices in ethnobotany. Ethno. Res. \& App., 5: 201-218.

6) Honig, M., Petersen, S., Shearing, C., Pintér, L., and Kotze, I. (2015) The conditions under which farmers are likely to adapt their behaviour: A case study of private land conservation in the Cape Winelands, South Africa. Land Use Pol., 48: 389-400.

7) Kartakusuma, R. (2006) Situs (Kabuyutan) Kawali di Ciamis, Jawa Barat: Ajaran Sunda di dalam Tatanan Tradisi Megalitik. In: Konferensi Internasional Budaya Sunda Jilid 1 pp. 254-271, Bandung: YKR.

8) Myers, N., Mittermeier, R. A., Mittermeier, C. G., da Fonseca, G. A. B., and Kent, J. (2000) Biodiversity hotspots for conservation priorities. Nature, 403(6772): 853-858.

9) Pannell, C. M. (1998) Aglaia elliptica. The IUCN Red List of Threatened Species 1998: e.T33726A9805994. http://www.iucnredlist.org/details/33726/0 (Accessed: 21Feb-2017).

10) Tallamy, D. W. (2009) Bringing nature home: how you can sustain wildlife with native plants. Timer Press, UK.

11) The Plant List (2013) The Plant List Version 1.1. http://www.theplantlist.org/ (Accessed: 1-Jan-2017).

12) Turner, N. J. (1988) The importance of a rose: Evaluating the cultural significance of plants in thompson and lilloet interior salish. J. American Anthropol., 90(2): 272-290.

13) Vodouhê, F. G., Coulibaly, O., Adégbidi, A., and Sinsin, B. (2010) Community perception of biodiversity conservation within protected areas in Benin. For. Policy \& Econ., 12(7): 505-512.

14) Wessing, R. (1999) The sacred grove: founders and the owners of the forest in West java. L'homme et La Foret Tropicale, 59-74.

（2017 年 6 月 2 日受理） 